\title{
"The current state of the energy market and monitoring of key issues in the innovation management system"
}

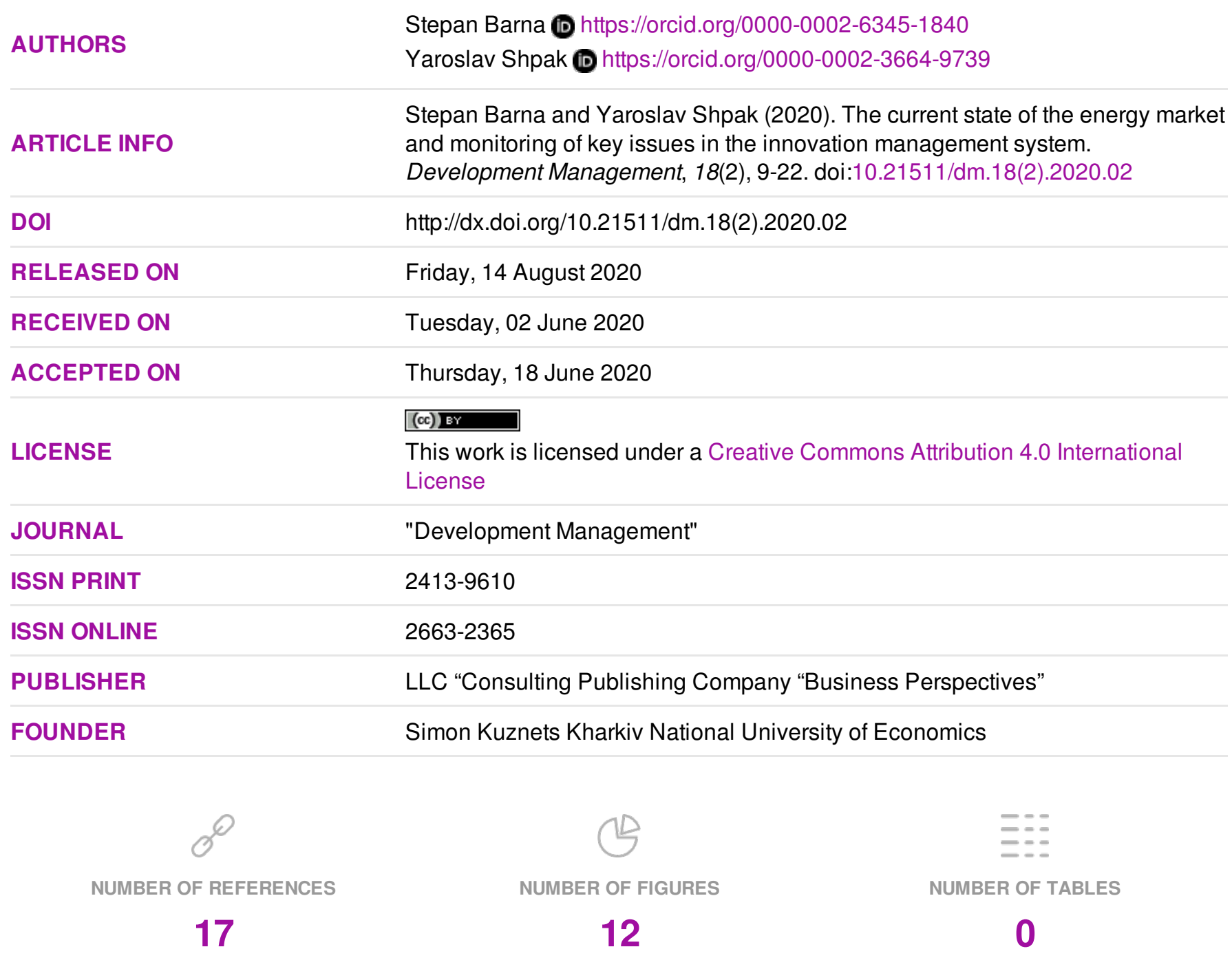

(C) The author(s) 2021. This publication is an open access article. 


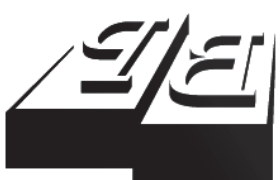

BUSINESS PERSPECTIVES

Publisher

LLC "CPC "Business Perspectives" Hryhorii Skovoroda lane, 10, Sumy, 40022, Ukraine www.businessperspectives.org

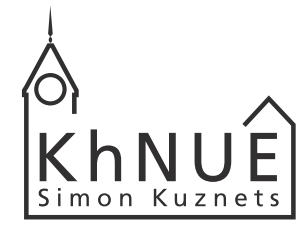

\section{S. KUZNETS KHNUE}

Founder

Simon Kuznets Kharkiv National University of Economics, Nauky avenue, 9-A, Kharkiv, 61166,

Ukraine

http://www.hneu.edu.ua/

Received on: 2nd of June, 2020 Accepted on: 18th of June, 2020 Published on: 14th of August, 2020

(c) Stepan Barna, Yaroslav Shpak, 2020

Stepan Barna, Researcher, Department of International Tourism and Hotel Business, Ternopil National University of Economics, Ukraine.

Yaroslav Shpak, Researcher, Department of International Tourism and Hotel Business, Ternopil National University of Economics, Ukraine.

\section{(c) (i)}

This is an Open Access article, distributed under the terms of the Creative Commons Attribution 4.0 International license, which permits unrestricted re-use, distribution, and reproduction in any medium, provided the original work is properly cited.

\title{
THE CURRENT STATE OF THE ENERGY MARKET AND MONITORING OF KEY ISSUES IN THE INNOVATION MANAGEMENT SYSTEM
}

\begin{abstract}
This paper considers the factors influencing the innovative development of energy service enterprises. The study aims to establish the relationship between the regulatory policy in the field of energy, the willingness of the population to use energy efficiency measures and the innovative potential of energy service companies. The generalization of scientific work on energy and environmental security has shown the relevance of developing mechanisms to reform the energy service market, taking into account the level of innovative development and management at the level of the energy service company. Accordingly, five energy companies from the western region of Ukraine (OJSC Ternopiloblenergo, PJSC Lvivoblenergo, JSC Chernivtsioblenergo, PJSC Rivneoblenergo, PJSC Volynoblenergo) were selected as objects for the study. Methodological research tools were the methods of focus group, personal interview, variations, statistical observation, induction, deduction, and generalization. The study presents external and internal factors influencing the innovative development of energy service enterprises. It is noted that the level of innovative development of personnel in the energy sector is low. The importance of strengthening cooperation of energy service enterprises with united territorial communities to implement the approved legal norms of energy market reform in Ukraine is taken into account. Among the measures to strengthen the motivation of the population to use energy-saving technologies, the intensification of media and information activities was noted. The results of the study can be useful for managers of energy service companies, heads of joint territorial communities and joint co-owners of apartment buildings, researchers working on energy efficiency projects.
\end{abstract}

\section{Keywords}

JEL Classification energy service companies, alternative energy, renewable energy sources, innovative development, innovative potential, energy and ecological safety

D69, L23, Q32, Q40

С. С. Барна (Україна), Я. О. Шпак (Україна)

\section{СУЧАСНИЙ СТАН ЕНЕРГОРИНКУ ТА МОНІТОРИНГУ КЛЮЧОВИХ ПРОБЛЕМ У СИСТЕМІ УПРАВЛІННЯ ІННОВАЦІЯМИ}

\begin{abstract}
Анотація
У статті розглядаються фактори впливу на інноваційний розвиток підприємств енергосервісу. Метою проведеного дослідження $\epsilon$ встановлення взаємозв'яків між регуляторною політикою у сфері енергетики, готовності населення до використання заходів з підвищення енергоефективності та інноваційним потенціалом енергосервісних компаній. Проведене узагальнення наукового доробку з питань забезпечення енергетичної та екологічної безпеки засвідчило актуальність розробки механізмів реформування ринку енергосервісу шляхом врахування рівня розвитку інновацій та управління ними на рівні енергосервісної компанії. Відповідно об'єктами для проведення дослідження обрано 5 енергокомпаній західного регіону України (ВАТ Тернопільобленерго, ПрАТ Львівобленерго, АТ Чернівціобленерго, ПрАТ Рівнеобленерго, ПрАТ Волиньобленерго), які $€$ основними надавачами послуг 3 енергопостачання у регіоні i, відповідно, відображають загальні тенденції формування енергосервісного ринку. Методологічним інструментарієм дослідження стали методи фокусгрупи, особистого інтервю, варіацій, статистичного спостереження, індукції, дедукції, узагальнення. У статті представлено зовнішні та внутрішні фактори впливу на інноваційний розвиток підприємств енергосервісу. Відзначено низький рівень інноваційного розвитку персоналу у сфері енергетики. Враховано важливість посилення співпраці підприємств енергосервісу з об'єднаними територіальними громадами з метою імплементації затверджених
\end{abstract}


правових норм реформування ринку енергії в Україні. Серед заходів з посилення мотивації населення до використання енергозберігаючих технологій відзначено активізацію медійно-інформаційної діяльності. Результати проведеного дослідження можуть бути корисними для менеджерів енергосервісних компаній, голів об'єднаних територіальних громад та об’єднаних співвласників багатоквартирних будинків, науковців, які працюють над проєктами з підвищення енергозбереження.

\section{Ключові слова}

Класифікація JEL

енергосервісні компанії, альтернативна енергетика, відновлювальні джерела енергії, інноваційний розвиток, інноваційний потенціал, енергетична та екологічна безпека

D69, L23, Q32, Q40

\section{ВСТУП}

Політика енергетичного ринку знаходиться у центрі уваги як усієї світової спільноти, так і є наріжним каменем забезпечення економічної стабільності вітчизняної економіки. Орієнтиром для посилення енергетичної незалежності та економії невідновлюваних джерел енергії $\epsilon$ усвідомлення вагомості новітніх форм надання високоякісних послуг у сфері заощадження джерел енергетики. Важливою ланкою у цьому технологічному, професійно-орієнтованому та інноваційно-спрямованому процесі $\epsilon$ діяльність енергетичних компаній, які займаються енергетичним обслуговуванням, реалізують проекти з енергоефективності й фінансуються на основі економії енергії.

Зважаючи на необхідність швидкого та значного збільшення фінансування енергоефективності, інтерес до бізнес-моделей енергозбереження зростає. Урядова політика є ключовим рушієм діяльності енергосервісних компаній і може впливати на те, чи здійснюються проекти в приватному чи державному секторі. Іншим важливим напрямком ефективності діяльності енергосервісних компаній $є$ особливості управління інноваціями в межах самого підприємства, від рівня розвитку якого залежить якість пропонованих послуг, їхня конкурентоспроможність на енергоринку.

\section{1. ЛІТЕРАТУРНИЙ ОГЛЯА}

Теоретичні та практичні аспекти реформування енергетичного ринку, забезпечення екологічної та енергетичної безпеки, перехід на використання відновлювальних джерел енергії як підприємствами, так і домогосподарствами, роль енергетичної політики у підвищенні соціальних стандартів представлені у працях Абрамова, Архангельського, Брича, Борисяк, Брю, Гамілової, Джеджули, Завербного, Климчук, Пальчук, Сотник, Федірка, Філюк, Чучалін, Шведун та ін. Окрема увага зосереджена на удосконаленні організаційно-економічного механізму управління інноваційною діяльністю підприємств в сфері житлово-комунального господарства, розвитку енергетики України в умовах євроінтеграції $[3,4,5$, 16], у томі числі методах управління ризиками [7], впровадженні інноваційних технологій управління персоналом [2, 5], енергетичного менеджменту [9], диверсифікації джерел отримання енергії $[4,10]$.

Климчук у [10] відзначає, що перспективи розвитку альтернативної енергетики залежать від характеру та особливостями управління нею, які полягають в необхідності вирішення проблем, що стримують розвиток підприємств альтернативної галузі. У свою чергу, Завербний у [16] акцентує увагу на важливості реформування українського ринку електричної енергії. Джеджула у [9] відзначає на створенні організаційно-економічного механізму енергозбереження промислових підприємств шляхом максимізації прибутку підприємства та збільшення його операційної і фінансової стійкості. Окремі дослідження $[3,8,12,15,16]$ присвячені розробці заходів щодо розвитку партнерства на рівні громади між органами місцевого самоврядування, населенням і надавачами енергетичних послуг у напрямі реформування житлово-комунального господарства на інноваційних засадах.

\section{2. МЕТА ДОСЛІДЖЕННЯ}

Метою статті є встановлення взаємозв'яків між регуляторною політикою у сфері енергетики, готовності населення до використання заходів з підвищення енергоефективності та інноваційним потенціалом енергосервісних компаній. 


\section{3. МЕТОДИ ДОСЛІДЖЕННЯ}

Методологічною основою для проведення дослідження стали такі методи: фокус-групи, особистого інтервю, варіацій, статистичного спостереження - для визначення умов функціонування підприємств енергосервісу для впровадження інновацій, поведінки споживачів енергоресурсів; індукції, дедукції - для встановлення факторних закономірностей впровадження інновацій на рівні підприємства, готовності персоналу до інноваційного розвитку; узагальнення - для формування заходів з використання інноваційного потенціалупідприємств енергосервісу як способудля зміцнення конкурентоспроможності на енергоринку.

\section{4. РЕЗУЛЬТАТИ}

3 метою оцінки загальних питань щодо сучасного стану енергоринку загалом та з'ясування ключових проблемв системіуправлінняінноваціямив енергосервіснихкомпаніяхнами булоініційованопроведення соціологічного дослідження, участь у якому взяли представники менеджменту 5 енергокомпаній західного регіону України: ВАТ Тернопільобленерго, ПрАТ Львівобленерго, АТ Чернівціобленерго, ПрАТ Рівнеобленерго, ПрАТ Волиньобленерго. Відбір експертів відбувся з числа відповідальних осіб, залучених до керівництва різними сферами енергокомпанії. Зокрема, у репрезентативну вибірку було задіяно 66 керівників та їх заступників із таких напрямків діяльності, як інформаційні технології та телекомунікації, обслуговування розподільчих мереж та питання приєднання, ізоляції та захисту від перенапруг, охорони праці та навколишнього середовища, перспективного розвитку, релейного захисту електроавтоматики і електровимірювання, диспетчерського і технічного керування тощо.

Державна підтримка $є$ важливою складовою у розбудові та інституційному забезпеченні нормативної діяльності підприємств, які надають відповідні послуги на енергоринку. Адже від законодавчого унормування питань заощадження різних видів енергії залежить не тільки стан енергобезпеки держави, можливості прийняття рішень на рівні місцевих органів влади, але й діяльність безпосередніх надавачів послуг на енергоринку. Більшість опитаних експертів вважають, що чинна нормативно-правова база у сфері енергетики лише частково відповідає сучасним вимогам.

Незважаючи на розгалужену нормативно-правову базу, яка регулює відносини об’єктів та суб’єктів надання й отримання енергопослуг, більшість експертів вказали на її часткову відповідність сучасним реаліям. Вочевидь діяльність профільних інституцій, таких як Міністерства енергетики та захисту довкілля, Державного агентства 3 енергоефективності та енергозбереження України вимагають більш дієвих ініціатив для налагодження продуктивної комунікації з усіма гравцями, які діють на енергоринку. Як помітно з Рисунку 1, є відчутний потенціал у розвитку нормативно-правової бази у сфері енергетики.

Регуляторна політика державних інституцій повинна забезпечувати баланс у правилах й умовах надання та отримання відповідних послуг у сфері енергетики. На думку науковців, введення в експлуатацію нових будівель або реновації старих без підвищення стандартів енергоефективності - це додавання ризику до вже існуючих загроз в екології та економіці [8, с. 15]. Загалом питання найбільш загрозливих для розвитку енергоринку ризиків, $є$ доволі актуальними і вимагають належного аналізу та узагальнення. За результатами дослідження, відповіді експертів на запитання щодо ключових загроз у розвитку енергоринку, є цілком суголосними з відповідями на попереднє запитання. Адже, як помітно з Рисунку 2, більшість експертів віднесли до першочергових ризиків відсутність доброчесної конкуренції на енергоринку. Як відомо, саме держава і органи державної влади є тими інституціями, на яких покладено завдання забезпечувати дотримання однакових правил для усіх учасників ринкових відносин. 3-поміж інших ризиків експерти вказали такі, як неплатоспроможність замовника, затримка в оплаті наданих послуг, надання недостовірної інформації тощо.

Критично незадовільними є показники щодо якості взаємодії між державою, органами місцевої влади та енергокомпаніями у питаннях розкриття інноваційних резервів на ринку енергетики. Споживання 


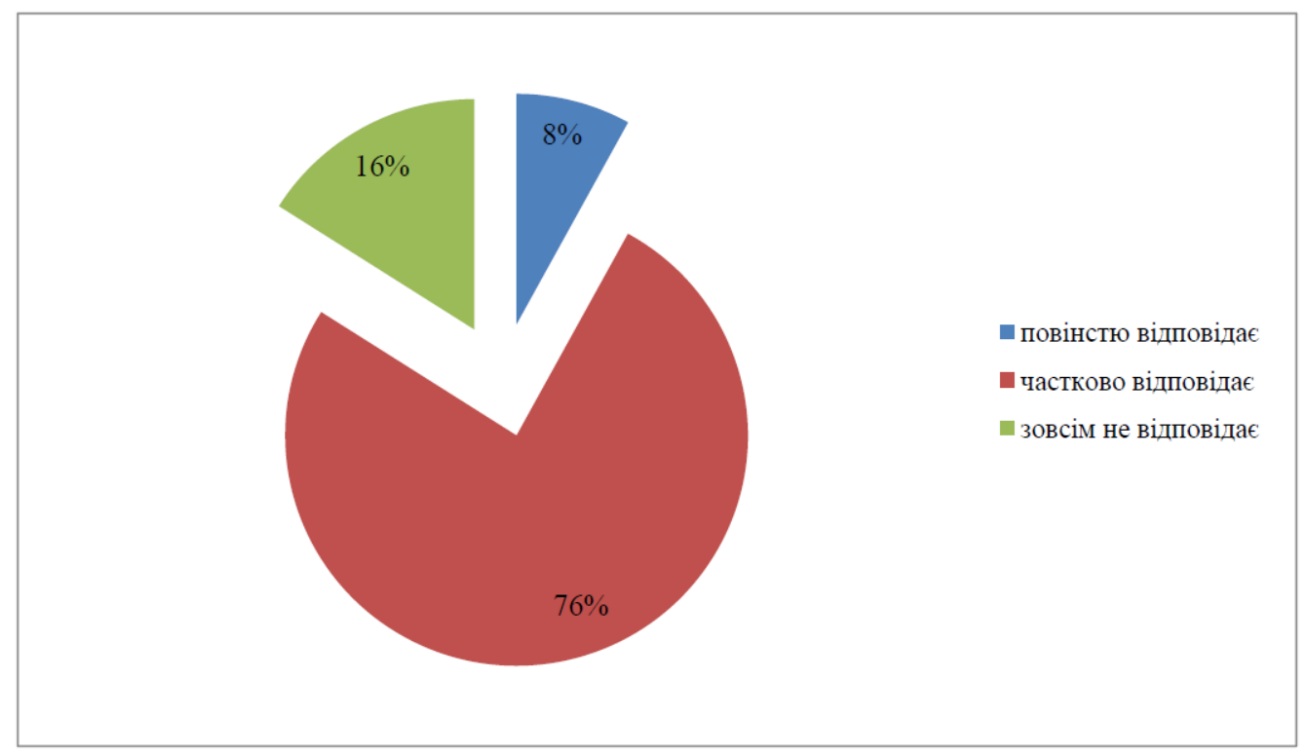

Джерело: Складено авторами.

Рисунок 1. Оцінка відповідності сучасним вимогам чинної нормативно-правової бази у сфері енергетики

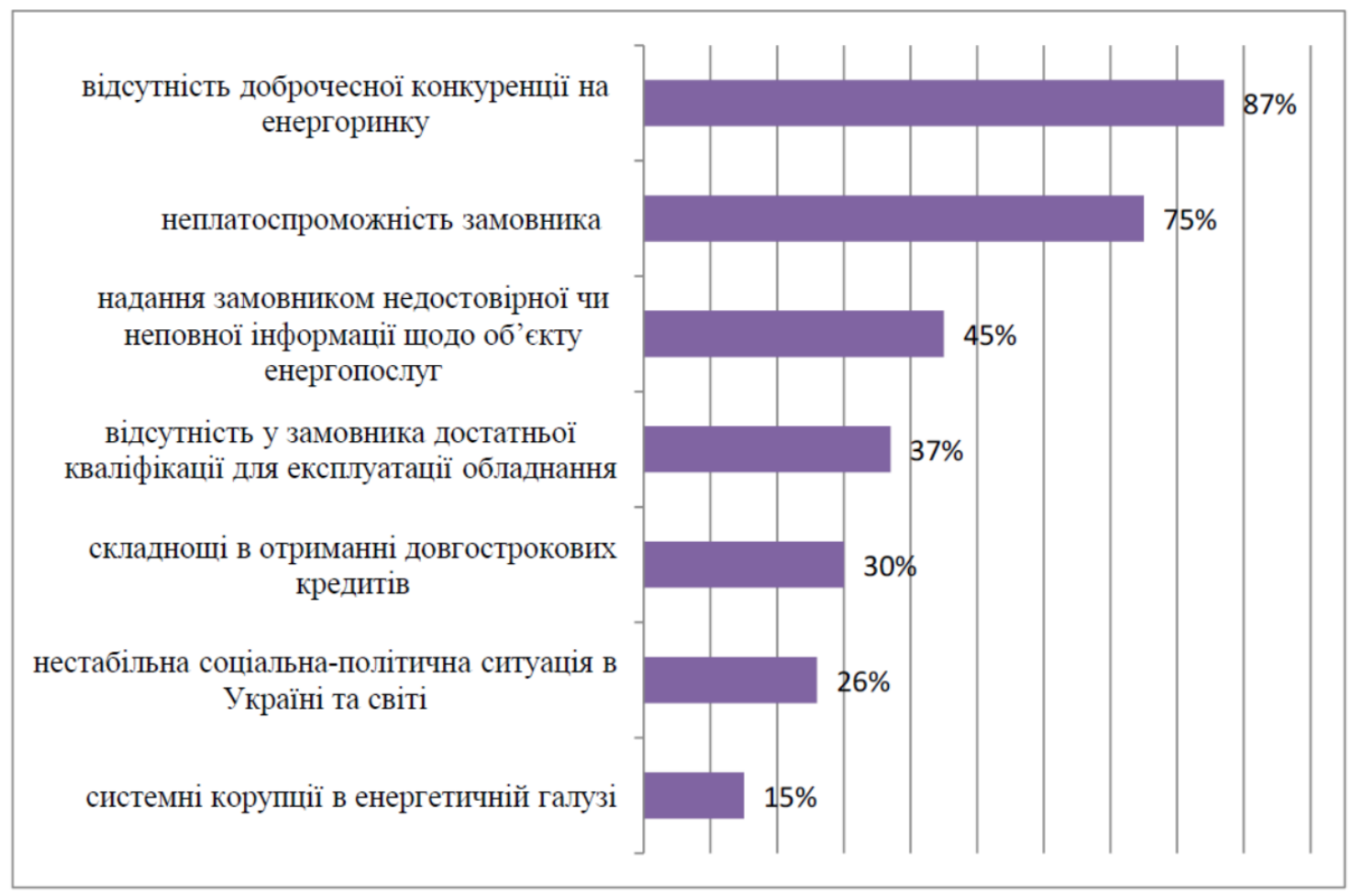

Джерело: Складено авторами.

\section{Рисунок 2. Ранжування найбільш загрозливими ризиків для розвитку енергоринку та надання якісних послуг}

теплової енергії, за визначенням фахівців, це найбільша стаття видатків при оплаті комунальних послуг для будь-якої громади. Ринкова ціна на теплову енергію ніколи не буде низькою, тому енергоефективність завжди лишається на часі. Утім, системний погляд на модернізацію теплової інфраструктури в громадах, усе ще мало поширений [12]. Відтак опитані нами експерти вказали на досить низький рівень взаємодії між сторонами, які безпосередньо зацікавлені в регуляції, отриманні та наданні відповідних послуг щодо посилення інноваційних потенціалів на ринку енергетики (Рисунок 3). 
Комунікація між споживачами і надавачами послуг $є$ важливим чинником ефективної політики із енергозбереження. Надавачі послуг, які задіяні у комплексному та професійному аудиті енергоефективності будівель й підприємств та мають відповідну компетентність, відзначають, що саме сфера освітлення потребує першочергового моніторингу інноваційних досягнень. Відповідно впровадження цих енергозберігаючих технологій є кроком до посилення енергетичної незалежності зацікавлених сторін. Як продемонстровано на Рисунку 4, думка опитаних експертів чітко відображає напрямок концентрації зусиль саме у сфері освітлення поряд з опаленням.

Підтримка та розкриття інноваційних резервів у галузі енергетичного обслуговування $є$ обопільною метою усіх зацікавлених сторін, оскільки від рівня розвитку енергокомпаній, їхніх технологічних можливостей залежить результативність політики у сфері енергозаощадження. Науковцями виокремлюються такі різновиди державної політики у сфері енергозбереження й енергоефективності, як політика енергозаощадження; політика енергоефективності; політика у сфері ефективного використання паливно-енергетичних ресурсів, енергозбереження, відновлюваних джерел енергії та альтернативних видів палива [15].

Відповідно, для успішної реалізації кожного з компонентів політики енергозаощадження необхідно на державному й місцевому рівнях за участі компаній з енергообслуговування долучатися до програм підтримки усього спектру інноваційних рішень, спрямованих на покращення заходів із енергозбереження. Більшість опитаних експертів відзначили, що першочергової уваги зі сторони органів центральної та місцевої влади, компаній 3 енергетичного обслуговування вимагає саме підтримка технологічних інновацій (Рисунок 5). Другим за важливістю виступає підтримка кадрового потенціалу, адже зрозуміло, що саме від фахової підготовки персоналу, компетентностей працівників залежить ефективність використання потужності підприємства, якість та швидкість впровадження нових підходів.

Посилена увага до технологічних інновацій $є$ важливою передумовою для уникнення так званого ефекту відскоку чи ребаунд-ефекту, обгрунтованого німецьким соціологом та економістом Сантаріусом [14]. Суть зазначеного ефекту полягає у збільшені використання енергоресурсів при підвищенні ефективності приладів за рахунок зростання їх кількості чи тривалості використання, внаслідок чого відбувається зменшення очікуваної вигоди від нових технологій. Ефект відскоку, зазвичай, відбивається

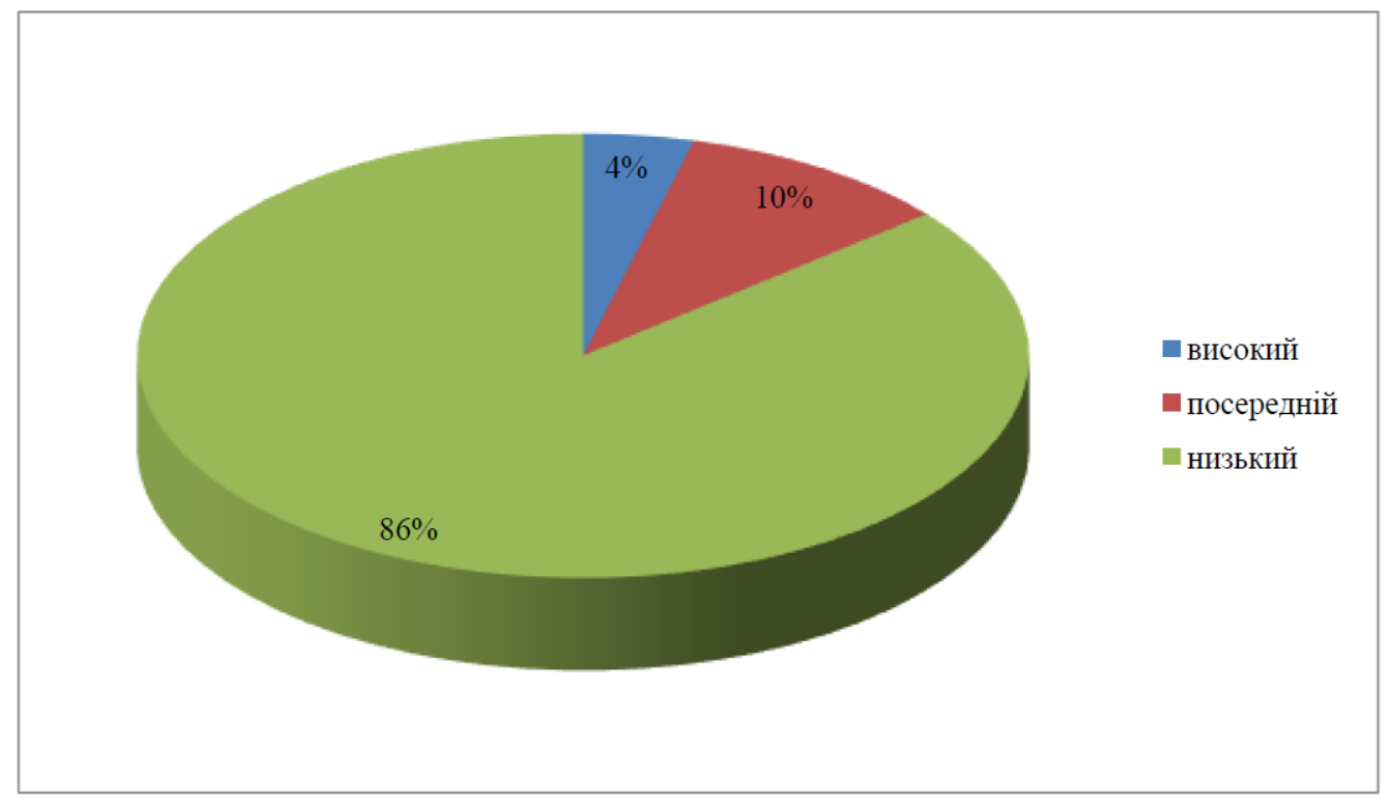

Джерело: Складено авторами

Рисунок 3. Оцінка рівня взаємодії між державою, органами місцевої влади та енергокомпаніями у питаннях розкриття інноваційних резервів на ринку енергетики 


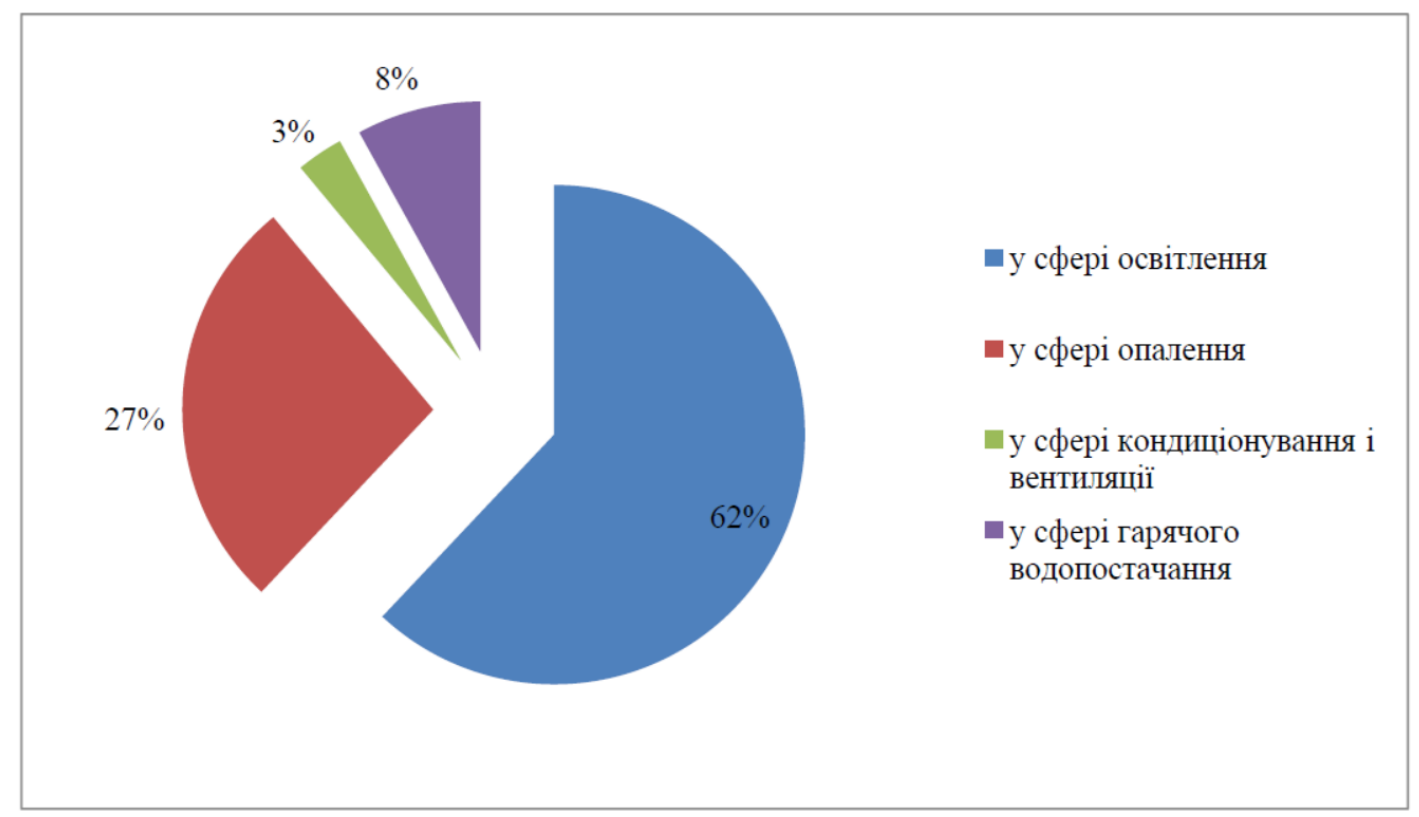

Джерело: Складено авторами.

Рисунок 4. Визначення пріоритетних сфер для впровадження енергозберігаючих технологій

у співвідношенні втраченої вигоди порівняно з очікуваною екологічною користю за умови, якщо споживання залишається на передньому рівні. За будь-яких обставин, як зазначають науковці, необхідно враховувати ризик виникнення ребаунд-ефекту при системному підході до енергозбереження: при реалізації комплексних програм (муніципальних, регіональних, державних, галузевих), розробці заходів стимулювання і державної підтримки, аналізі фактичних показників енергоспоживання та динаміки їх зміни [11, с. 19].

У контексті посилення конкурентних переваг енергокомпаній варто звернути увагу на такий мало задіяний ресурс як медійно-інформаційний. За результатами загальноукраїнського соціологічного дослідження, населення України має досить суперечливе ставлення до ефективності енергозберігаючих технологій в контексті зниження вартості комунальних послуг. 3 одного боку, 71\% українців вважають, що впровадження відповідних технологій дозволяє знижувати вартість комунальних послуг для домогосподарств (не вважають так - 2\%). 3 іншого боку, 46\% вважають, що у разі впровадження енергозберігаючих технологій уїхніх домогосподарствах можливість заощадити буде незначною (не вважають так 27\%) [1]. Щодо питань обізнаності і бажання взяти участь у програмах підвищення енергоефективності, то принаймні про одну програму з впровадження енергоефективних заходів знають лише 29\% жителів України [1]. Отже, вважаємо за необхідне звернути увагу на систему внутрішньої політики підприємства щодо заходів із поширення інформації про очікуванні джерела економії коштів, просвітницьку роботу серед населення з питань переваг застосування енергоощадливих технологій та спектру послуг, які надаються підприємством.

Як засвідчують самі експерти меді-комунікативний потенціал розкрито недостатньою мірою. Лише $12 \%$ респондентів зазначили, що їхні компанії досить часто, тобто декілька разів на місяць, виходять на ринок медіакомунікації із потенційними споживачами. 80\% вказали, що така комунікація відбувається лише декілька разів на півроку, а 8\% проводять досить пасивну політику щодо інформування населення про спектр своїх послуг, здійснюючи вплив на потенційних споживачів декілька разів на рік.

Відзначимо, що задіяння медіа-комунікативного потенціалу у добу, перш за все, інформаційного конкурування, є вагомим чинником для нарощування та розкриття переваг підприємства 3-поміж інших, які надають аналогічні послуги.

Критично важливим напрямком розвитку галузі енергоощадливих технологій є активна наукова розробка власних інноваційних рішень поряд із залученням в арсенал діяльності підприємства 


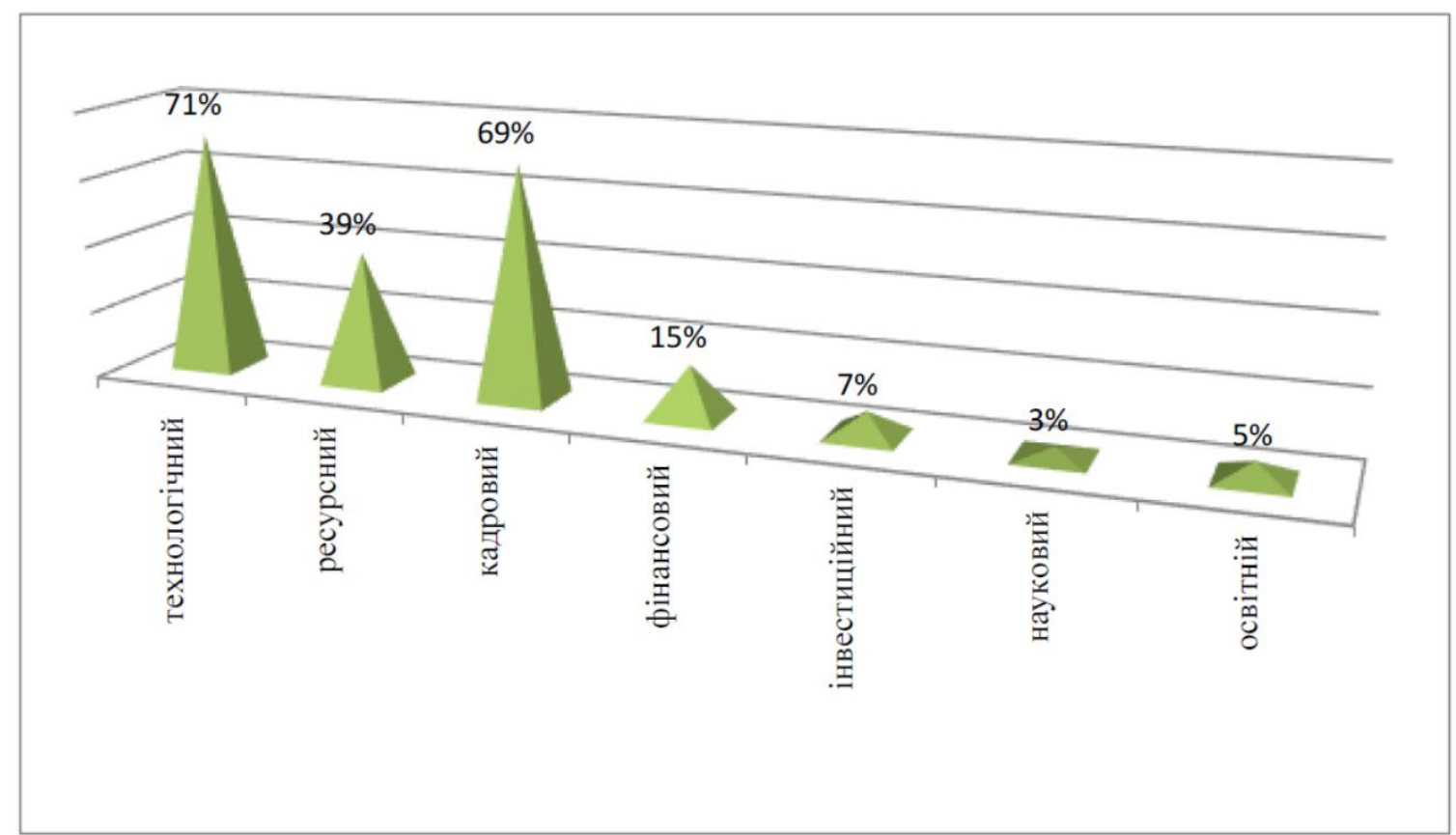

Рисунок 5. Розподіл відповідей щодо першочерговості підтримки інноваційних резерви зі сторони держави, органів місцевої влади та компаній з енергетичного обслуговування

передових напрацювань вітчизняних та закордонних фахівців. За свідченням опитаних експертів у системі розробки та впровадження інноваційних рішень лідируючі позиції займають спільні проекти із фахівцями в галузі енергетики. Натомість власні дослідження фахівцями компанії, як показано на Рисунку 6, займають незначну частку у продукуванні інноваційних рішень.

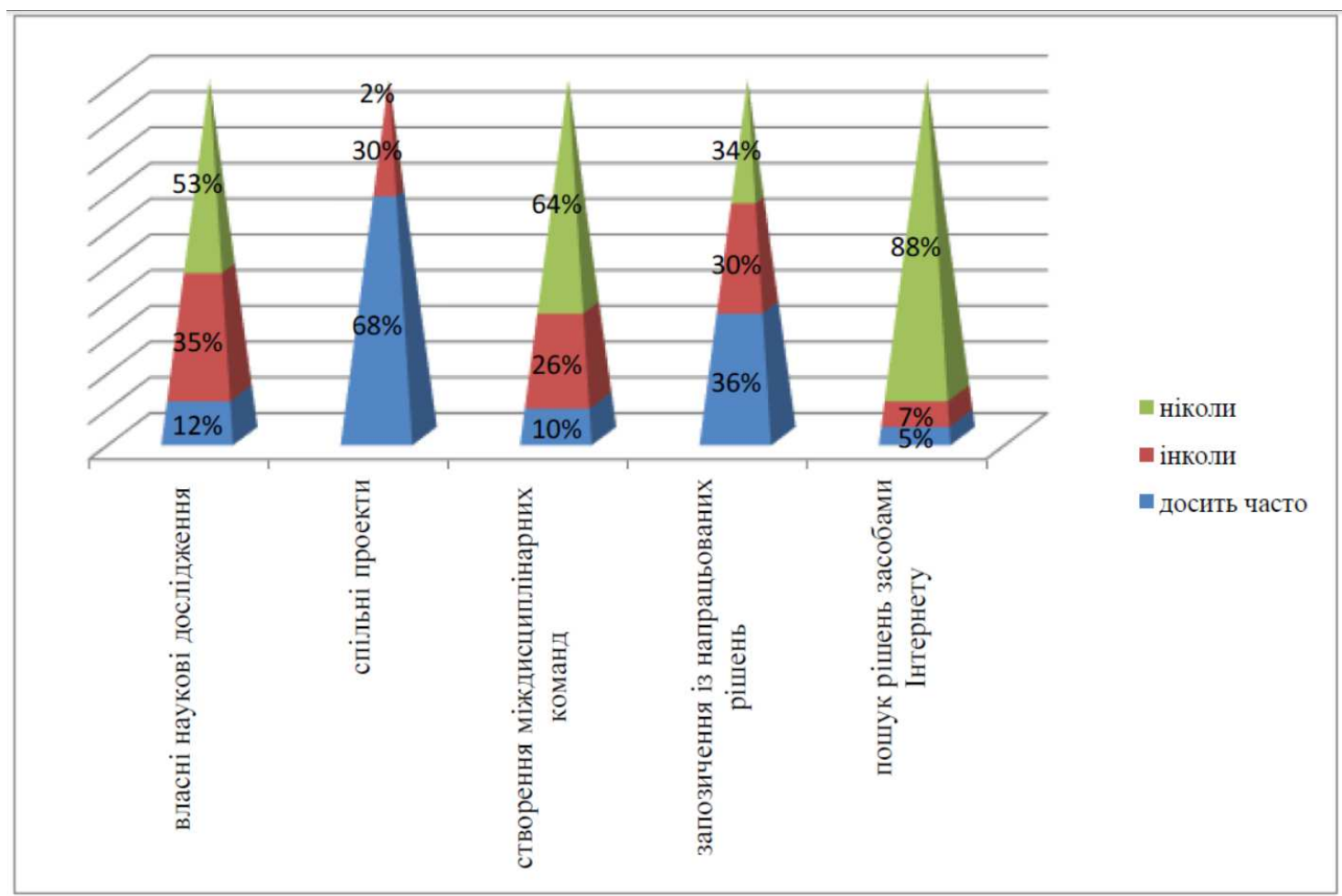

Джерело: Складено авторами

Рисунок 6. Ранжування методів розробки та впровадження інноваційних рішень на енергопідприємствах 
Ми погоджуємось із думкою науковців, які стверджують, що держава часто діє повільно і неефективно в системі нарощування інноваційних рішень, в той час як професійні кола й представники громадськості, об’єднані спільною метою, досягають результативності значно швидше. Чучалін пропонує такі заходи, спрямовані на генерування нових ідей, вільний та безкоштовний обмін ідеями, кращими практиками, дослідженнями, історіями успіху:

- наукові дослідження;

- відслідковування змін у законодавстві та розробка пропозицій щодо його вдосконалення;

- поради з енергозбереження для широких верств населення;

- представлення успішних проектів з енергоефективності;

- рекомендації кращих енергоефективних технологій, обладнань та матеріалів;

- фінансування енергоефективних проектів;

- вивчення зарубіжного досвіду;

- ініціювання та проведення конференцій, презентацій, семінарів 3 проблем енергозбереження та енергоефективності [8, с. 14].

Показником результативності діяльності компанії, яка намагається зайняти лідируючі позиції на конкурентному ринку з високою часткою ризиків різного характеру, є їі внутрішній потенціал. Продукування інноваційних рішень для задоволення зростаючих потреб у сфері енергозберігаючих технологій щільно пов'язані із інноваціями у системі управління самої компанії. Отже, чітко відслідковується процесуально-результативний взаємозв'язок між зовнішніми досягненнями підприємства та внутрішніми управлінськими стратегіями. Нами були зафіксовані доволі невтішні результати у частині того, як експерти оцінюють здатність використовувати внутрішні ресурси компанії для досягнення бажаного інноваційного результату. 66\% респондентів вказали, що у їхніх компаніях лише частково вдається отримати бажаний результат за рахунок внутрішніх резервів, $12 \%$ експертів переконані у здатності своїх підприємств повною мірою акумулювати потенціали підприємства для випуску відповідної продукції, удосконалення технологічних процесів), а 22\% опитаних визнали низьку здатність підприємства акумулювати внутрішні ресурси для продукування та реалізації інноваційних рішень. Зафіксовані тенденціїпосилюють увагу керівництва до стратегії менеджменту енергопідприємств.

3 метою з'ясування ключових труднощів у системі внутрішнього менеджменту енергокомпаній нами було встановлено їхній перелік, представлений на Рисунку 7.

Отже, перелічені проблеми можна поділити на екзогенні та ендогенні, перші з яких сутнісно пов’язані із недоліками в організації внутрішньо-фірмового стратегічного управління, відповідно, другі викликані зовнішніми обставини, які впливають на якість діяльності підприємства. Причому перша група $\epsilon$ переважаючою, на що вказують отримані результати. Саме питання відсутності усталеної стратегії управління енергокомпанією та спільного бачення досягнення кінцевого результату топ-менеджменту визначаються експертами як першочергові у системі менеджменту підприємства.

Також за результатами дослідження було встановлено, що на більшості підприємств спостерігаються недосконалість планування сталого енергетичного розвитку щодо зменшення СО2 на місцевому рівні. Лише $15 \%$ опитаних експертів зазначили про наявність такого плану на їньому підприємстві (Рисунок 8).

Планування діяльності будь-якої компанії є наріжним завданням для визначення коротко-, середньота довгострокових перспектив діяльності. Галузь енергоощадливих технологій та надання відповідних послуг є доволі динамічною і залежить від зміни політичних орієнтирів як всередині держави, так i тенденцій на міжнародному ринку. Також варто передбачати й стрімкі зміни в технологічних аспектах, які супроводжують усі сфери народного господарства. Відповідної уваги вимагають темпоральні складові у плануванні діяльності енергокомпаній, наявність чіткого бачення поточного стану енергоринку та його можливі трансформації у найближчому та віддаленому майбутньому. Натомість нами зафіксована тенденція до переважно короткотермінового планування діяльності енергокомпаній. Як помітно з рис. 9, на більшості підприємств поширена практика орієнтації на найближчу перспективу, на що вказала 


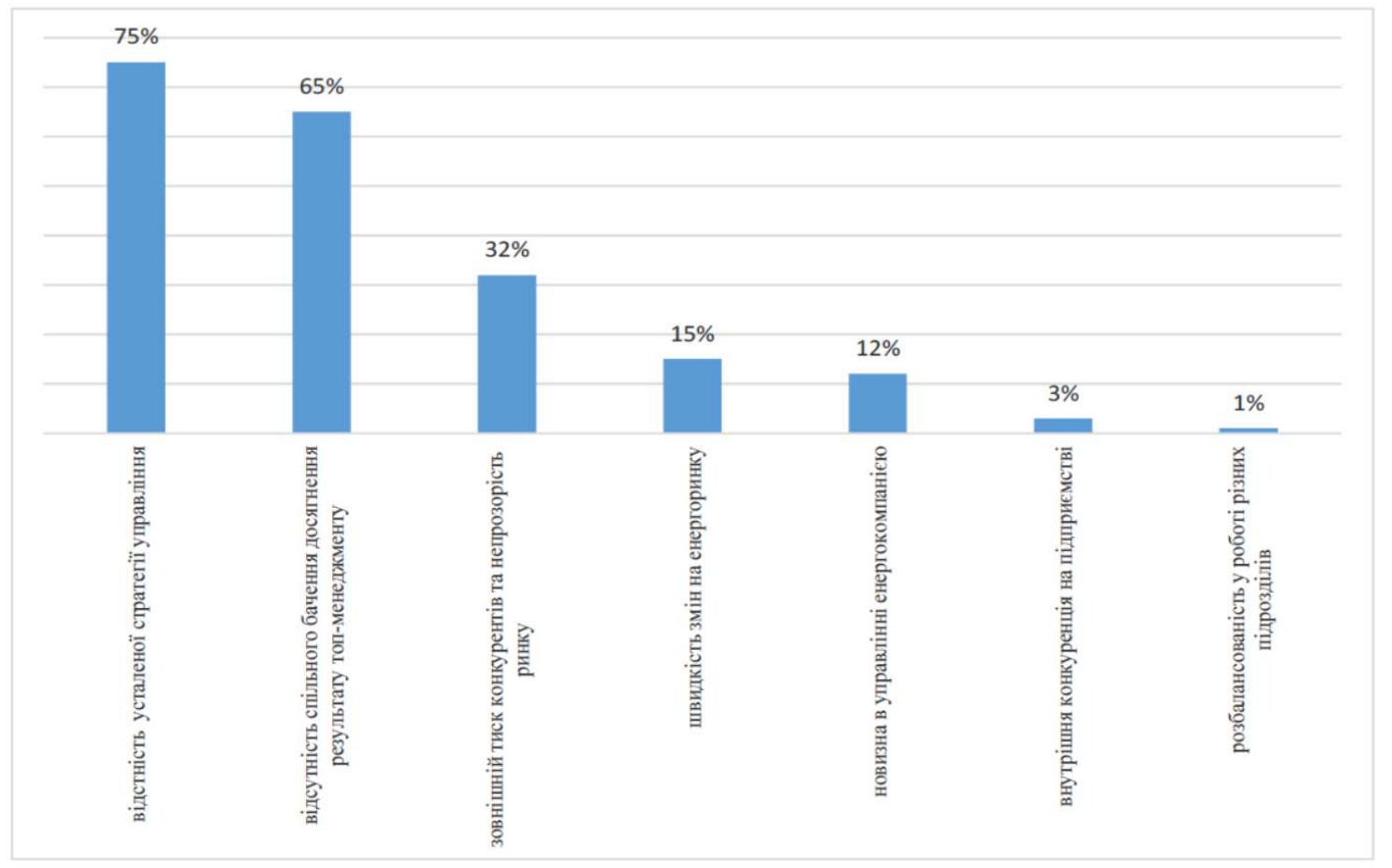

Джерело: Складено авторами

Рисунок 7. Ранжування ключових труднощів у системі менеджменту енергокомпаній

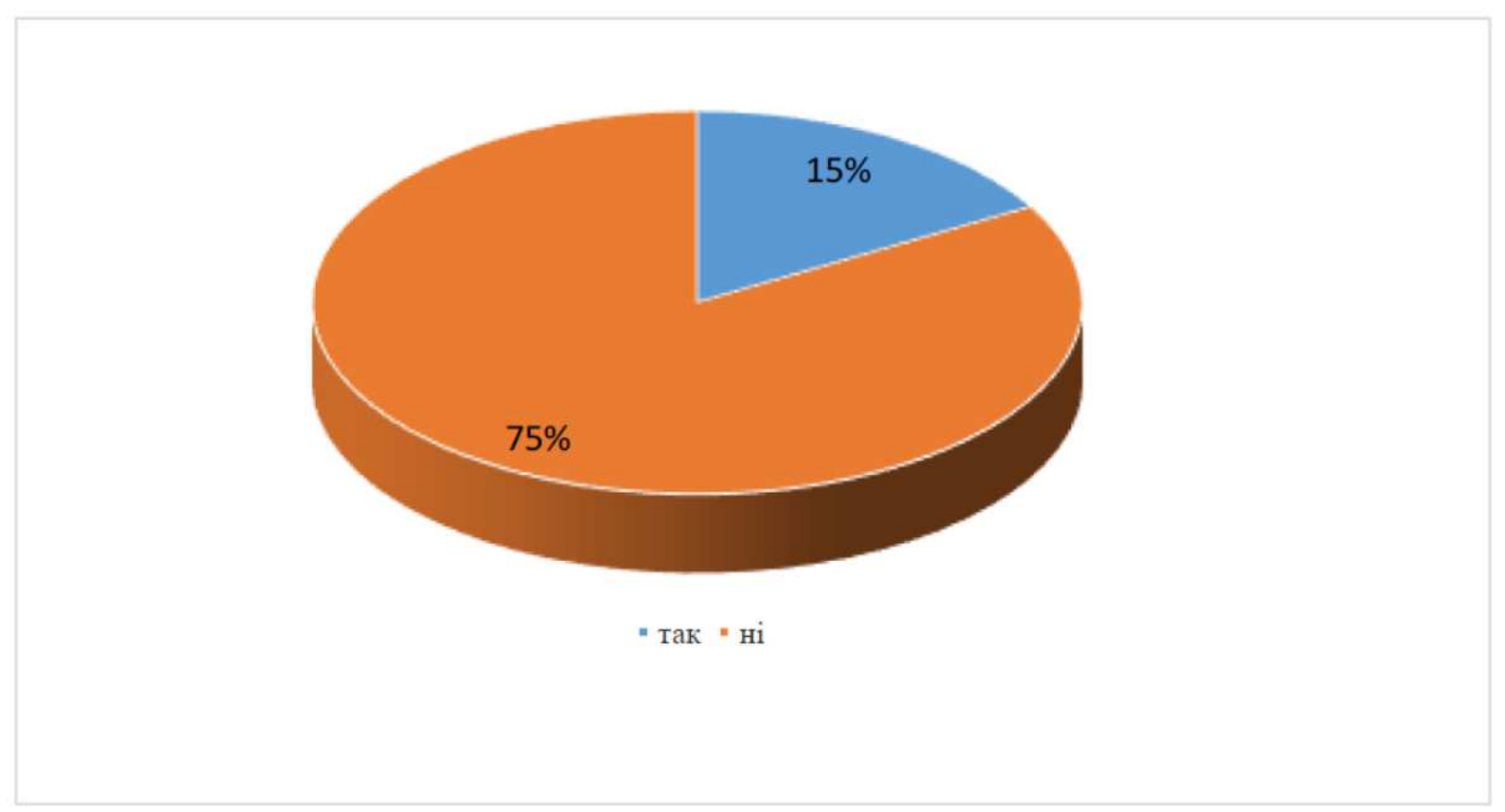

Джерело: Складено авторами.

Рисунок 8. Розподіл відповідей щодо наявності на підприємстві плану сталого енергетичного розвитку та зменшення $\mathrm{CO} 2$ на місцевому рівні 
більшість опитаних експертів. Лише 10\% респондентів відзначили, що на їхніх підприємствах існують плани діяльності на 5 і більше років. Переважна ж більшість обмежуються перспективними планами в діапазоні від одного року до двох.

Складнощі проявляються також і в якості підготовки штатних працівників для виконання професійних завдань. Як зазначили опитані експерти рівень компетентності та інноваційної зорієнтованості працівників фірми знаходиться на позначці вище середнього (Рисунок 10).

Більшістю респондентів рівень кваліфікації залучених до професійної діяльності працівників оцінений на 6 балів з 10 можливих (за критерієм, де 1 - абсолютно не компетентні, 10 - повністю компетентні).

Частково така ситуація пояснюється відсутністю повномасштабного впровадження практики навчання основам інноваційного менеджменту на підприємстві. Лише $16 \%$ менеджерів вказали на повну реалізацію програм навчання основам інноваційного управління, $67 \%$ відзначили, що така практика поширена лише частково і 17\% опитаних визнали відсутність будь-яких заходів із навчання основам інноваційного менеджменту. Вважаємо, що на сучасному підприємстві з високою часткою економічних і технологічних ризиків, усі працівники $є$ спільною командою, якій має бути притаманне неординарне бачення просування на ринку енергопослуг. Практичні методи формування інноваційної стратегії організації, розробки й економічного обгрунтування інноваційних проектів $€$ питаннями підтримки конкурентних переваг, необхідною передумовою утримання лідируючих позицій у ситуаціях невизначених траєкторій соціально-політичного поступу.

3'ясовано, що ключовими перешкодами у процесі реалізації нововведень під час надання послуг $€$ відсутність відповідної компетентності персоналу у питаннях інноваційної діяльності та складність у впровадженні актуальних методик й алгоритмів економічного обгрунтування проекту (Рисунок 11). Врахування вказаних бар’єрів та орієнтація на їх усунення $€$ першочерговим завданням із підвищення ефективності діяльності енергокомпаній.

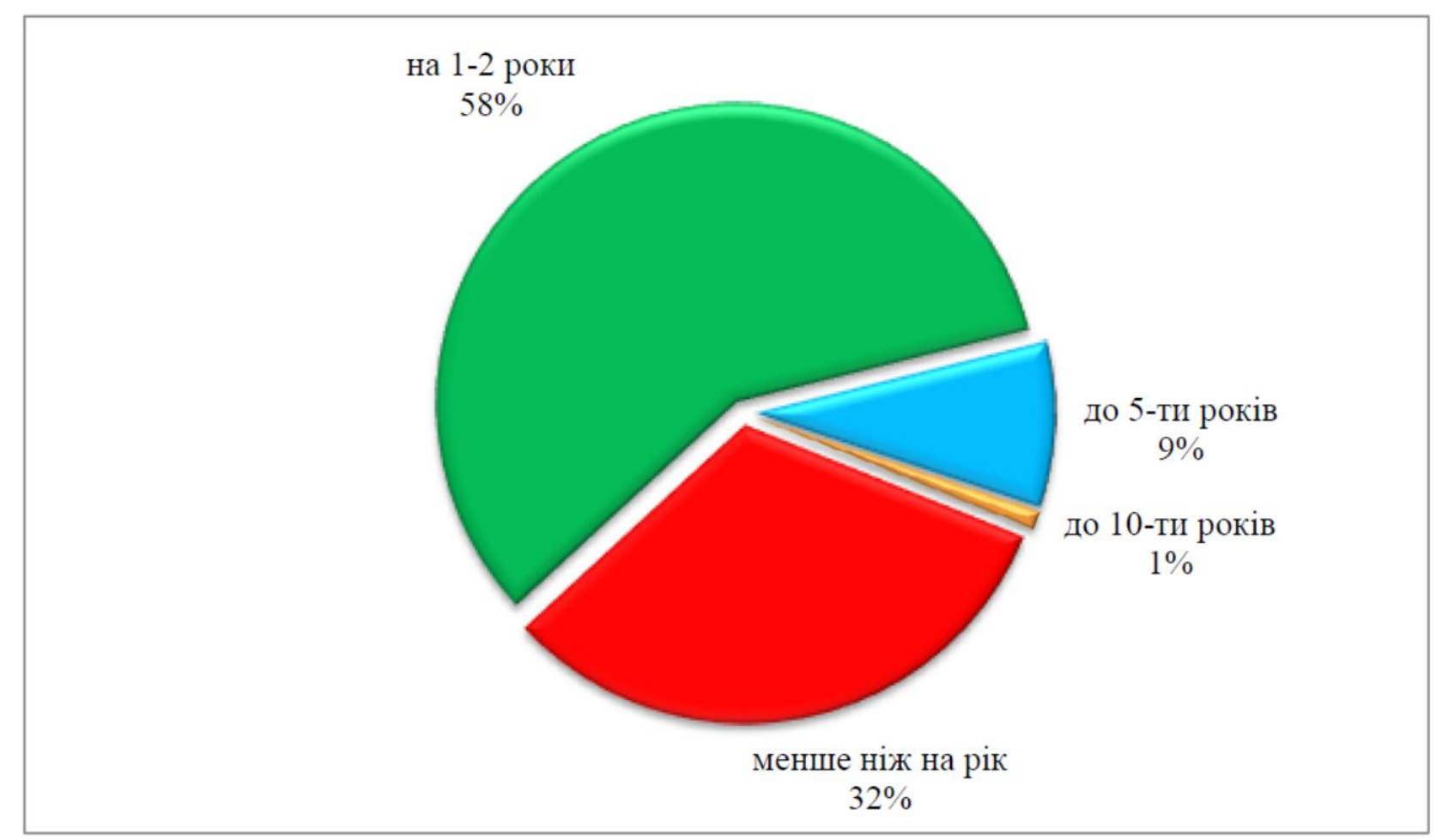

Рисунок 9. Перспективний період планування діяльності енергокомпаній 


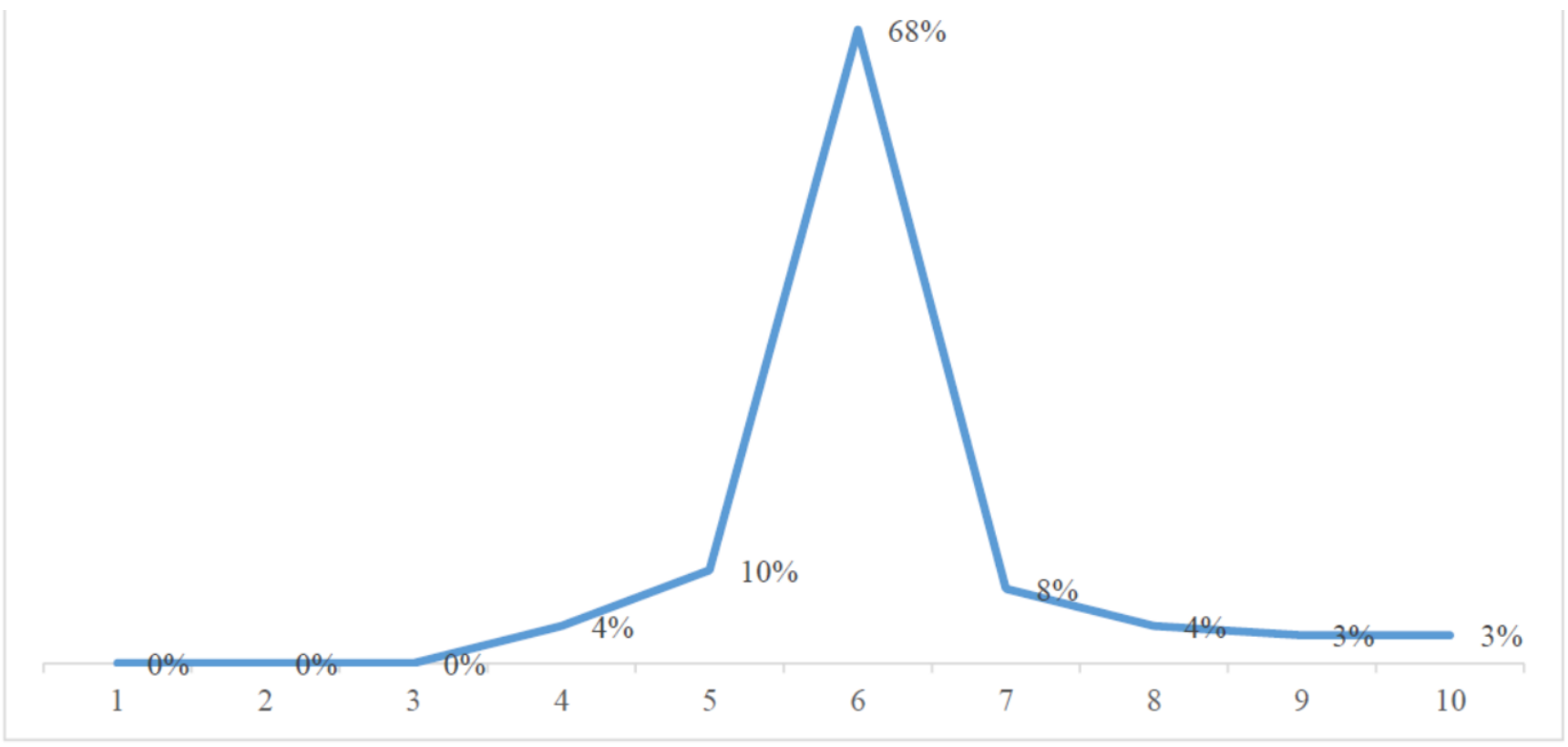

Джерело: Складено авторами.

Рисунок 1о. Оцінка рівня компетентності та інноваційності команди працівників фірми, діяльність яких спрямована на досягнення загальної мети

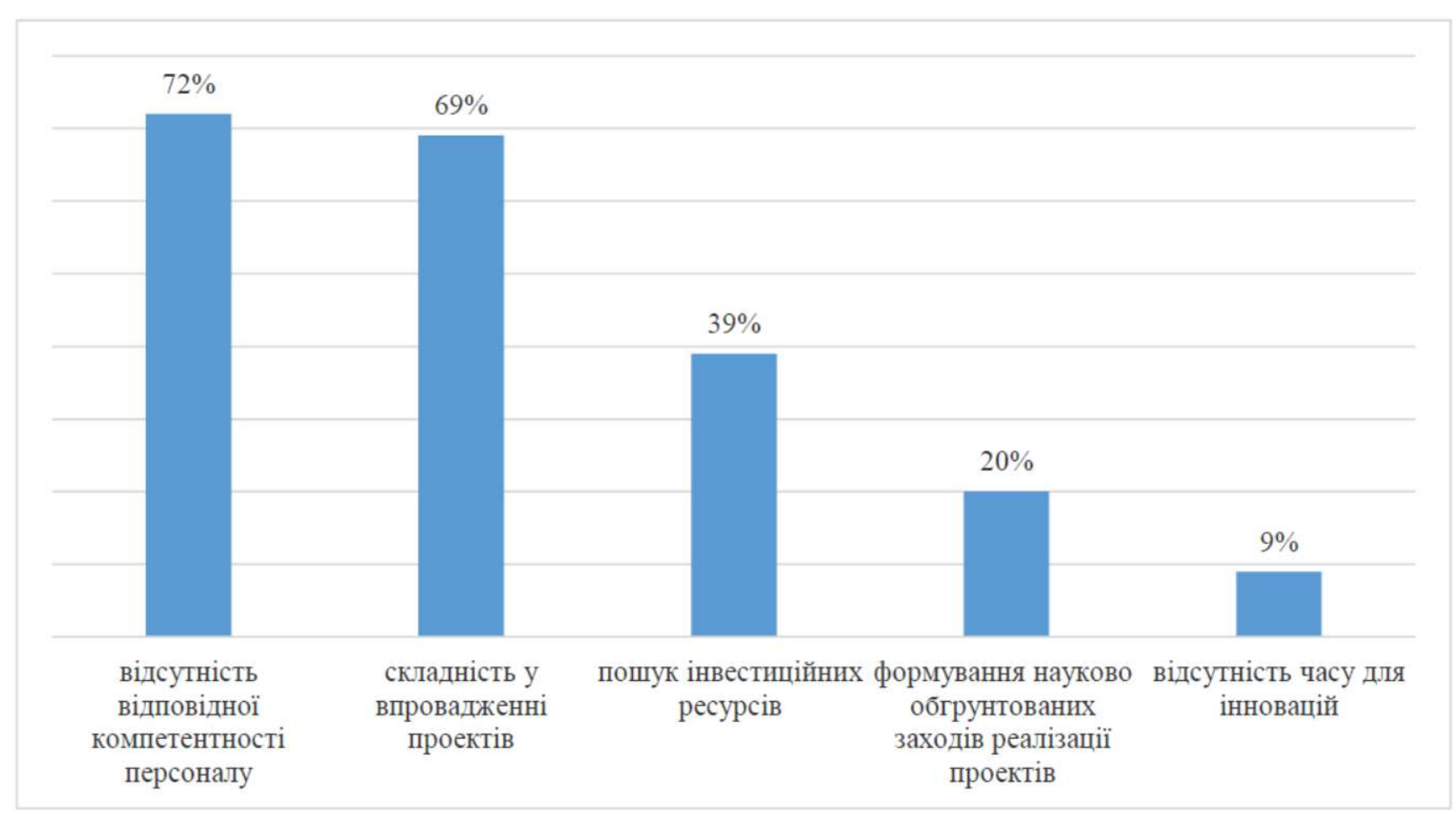

Джерело: Складено авторами

Рисунок 11. Розподіл відповідей щодо ускладнень при ідентифікації та реалізації нововведень у процесі надання послуг

Безперервність у навчанні персоналу є стратегічним організаційним завданням для підтримки на належному рівні освітнього потенціалу підприємства. Впровадження ефективної платформи навчання $€$ не тільки показником прогресивної орієнтації компанії, але й дієвим інструментом впливу на якість кадрового складу. Працівники, які регулярно залучаються як до внутрішніх, так і зовнішніх освітніх 
ініціатив стають, з одного боку, носіями сучасних та актуальних знань у своїй галузі діяльності, 3 іншого, здатні не тільки відтворювати передовий досвід, але й продукувати нові, інноваційні рішення, що, беззаперечно, впливає на якість надання послуг. В умовах сучасного швидкого старіння теоретичних знань, умінь та практичних навичок, як зазначають вітчизні економісти, спроможність організації постійно здійснювати розвиток своїх працівників є одним з найважливіших факторів забезпечення

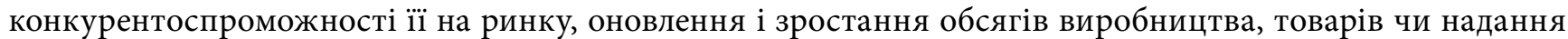
послуг [13].

За результатами опитування експертів встановлено, як продемонстровано на Рисунку 12, що найбільш часто на підприємствах звертаються до такого джерела передачі знань, як обмін знаннями на робочому місці (54\% опитаних), інколи практикується робота з наставником (60\% опитаних), проведення психологічних тренінгів (40\%), індивідуальний і груповий коучинг (30\%) та організаційні ігри (15\%). Аналіз отриманих даних засвідчує відсутність сталої політики навчання основам інноваційного менеджменту на підприємствах, що актуалізує питання розробки інституційних механізмів налагодження міцної освітньої платформи.

Освіта і навчання персоналу, зауважують науковці, повинні бути безперервними і забезпечувати необхідний розвиток персоналу, який може бути загальним і професійним [17]. Додамо, що володіння основами інноваційного менеджменту - це, перш за все, володіння розвинутим інноваційним мисленням та навичками генерування нових ідей для виробництва та збуту нових товарів та послуг. Інновації в менеджменті сприяють швидкому та ефективному координуванні інноваційними процесами, правильному оперуванні стратегічною інформацією й спрямуванні їі на прийняття й впровадження нових рішень.

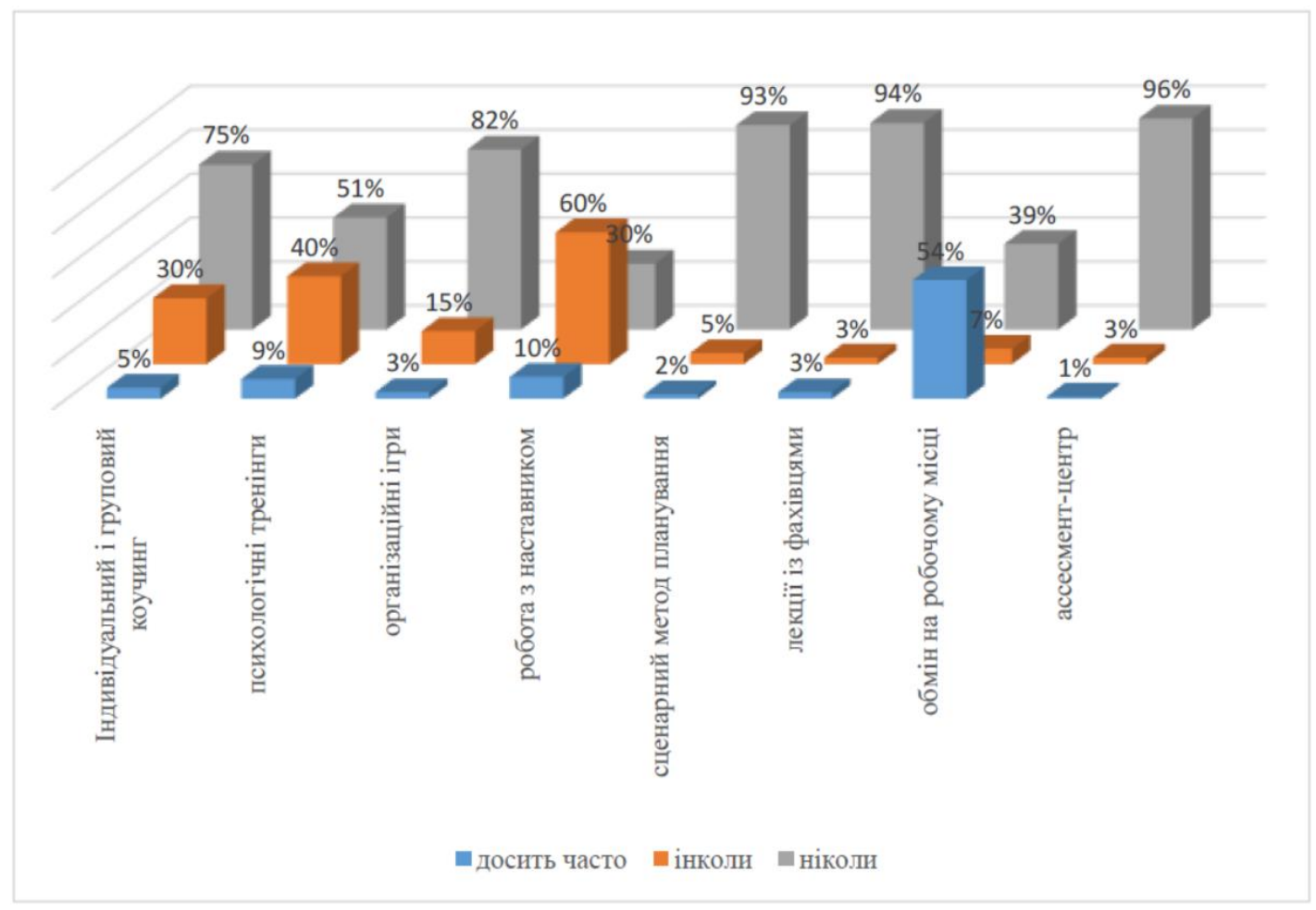

Джерело: Складено авторами

Рисунок 12. Частота використання програм навчання основам інноваційного менеджменту 


\section{ВИСНОВКИ}

Отже, більшість опитаних експертів визнали, що нормативно-права база у сфері енергетики лише частково відповідає тим реаліям, які склалися на сьогочасному ринку надання енергопослуг. Недосконалість правового забезпечення, як наслідок, загострює загрози для розвитку надання якісних послуг енергокомпаніями. Відсутність доброчесної конкуренції на енергоринку, на думку експертів, $\epsilon$ першочерговою загрозою для розвитку чесного та прозорого бізнесу. Відповідно, державі, у партнерстві з усіма зацікавленими сторонами, необхідно доклади зусиль для унормування цих процесів. Значне занепокоєння експерти виявили щодо якості та продуктивності взаємодії між державою, органами місцевої влади та енергокомпаніями, вважаючи, що у питаннях розкриття інноваційних резервів відсутня злагоджена співпраця.

Крім того, експерти саме сферу освітлення визнали провідною для моніторингу інноваційних досягнень та впровадження енергозберігаючих технологій. Натомість особливої уваги вимагають підтримки технологічний та кадровий потенціали, між якими існує тісний зв’язок. Технологічні потужності підприємства, його інноваційні спроможності залежать від кадрового складу підприємства, його здатності вміло й ефективно використовувати наявні ресурси. Рівень компетентності працівників енергосервісних компаній опитані експерти визнали як достатній, проте існує значний резерв для посилення освітнього потенціалу кадрового складу. Вважаємо, що запровадження згармонізованої системи навчання основами інноваційного менеджменту на постійній основі $є$ одним із ключових завдань керівництва енергокомпаній.

Задля посилення конкурентних переваг підприємства, налагодження продуктивної взаємодії між усім учасниками енергоринку нами була звернена увага на розвиток медійно-інформаційного ресурсу. Вдале просування ідей енергозаощадження, інформування населення, місцеві органи влади про ефективні програми економії коштів за рахунок впровадження нових технологій $є$ дієвим компонентом інноваційного менеджменту на підприємствах, які надають відповідні послуги. До того ж позитивним $\epsilon$ факт, на що вказали експерти, наявність співпраці у межах спільних проектів із фахівцями в галузі енергетики щодо розробки та впровадження інноваційних рішень. Натомість питома вага власних наукових досліджень, створення міждисциплінарних команд із фахівців різних галузей $є$ доволі низькою.

Управління інноваціями в енергосервісних компаніях наштовхується на низку бар'єрів, які, за результатами акумуляції відповідей опитаних експертів, нами були визначені як екзогенні та ендогенні, перші з яких пов’язані з труднощами внутрішнього менеджменту. Як наслідок, предметом для проведення подальших досліджень $є$ розробка стратегічного плану інноваційного розвитку, що сприятиме формуванню спільного бачення досягнення кінцевого результату топ-менеджменту та упередження накопичення управлінських конфліктів.

\section{AUTHOR CONTRIBUTIONS}

Conceptualization: Stepan Barna.

Data curation: Stepan Barna.

Formal analysis: Yaroslav Shpak.

Funding acquisition: Yaroslav Shpak, Stepan Barna.

Investigation: Yaroslav Shpak, Stepan Barna.

Methodology: Stepan Barna.

Project administration: Yaroslav Shpak.

Resources: Yaroslav Shpak, Stepan Barna.

Supervision: Stepan Barna.

Validation: Stepan Barna.

Visualization: Yaroslav Shpak.

Writing - original draft: Yaroslav Shpak, Stepan Barna.

Writing - review \& editing: Yaroslav Shpak, Stepan Barna. 


\section{СПИСОК ЛІТЕРАТУРИ}

1. Akermann, A., Koval-Honchar, M., Hrushetskyi, A., \& Lypova, P. (2019). Dumky i pohliady naselennia Ukrainy shchodo enerhoefektyvnosti i enerhozberezhennia. Rezultaty vseukrainskoho sotsiolohichnoho opytuvannia [Opinions and views of the population of Ukraine on energy efficiency and energy saving. Results of the all-Ukrainian sociological survey]. (In Ukrainian). Retrieved from https://ecoaction.org.ua/wp-content/uploads/2019/11/ energy-saving_2019_web-s.pdf

2. Borysiak, O. (2018). Optimization challenges in the personnel management system on the enterprises. Ekonomichnyi visnyk Zaporizkoi derzhavnoi inzhenernoi akademii - Economic Bulletin of the Zaporozhye State Engineering, 13(1), 78-82. (In Ukrainian). Retrieved from http://nbuv.gov.ua/UJRN/ evz-dia_2018_1_17

3. Brych, V., \& Borysjak, O. (2017). Sotsialna polityka v sferi zhytlovoho budivnytstva [Social policy in the field of housing construction]. Sotsialno-ekonomichnyi rozvytok rehioniv $v$ konteksti mizhnarodnoi intehratsii - Socio-economic development of regions in the context of international integration, 27(16), 212-216. (In Ukrainian). Retrieved from https://cutt.ly/3a78jOx

4. Brych, V., \& Ghevko, B. (2016). The problems of the use of solar energy in the sphere of housing and communal services. Innovative economy, 1-2, 152-157. (In Ukrainian). Retrieved from http://nbuv.gov.ua/UJRN/inek_2016_1-2_26

5. Brych, V., Fedirko, M., \& Borysjak, O. (2018). Approaches to implementing technologies of personnel management in thermal power enterprises. Herald of Ternopil National Economic University, 4(90), 99-110. (In Ukrainian). https://doi.org/10.35774/visnyk2018.04.099

6. Brych, V., Fedirko, M., \& Janik, I. (2016). Orhanizatsiino-ekonomichni peredumovy reinzhynirynhu biznes-protsesiv na rynku komunalnoi teploenerhetyky Ukrainy [Organizational-economic conditions of business process reengineering in the market municipal heating Ukraine]. Herald of Ternopil National Eco-nomic University, 2, 7-19. (In Ukrainian). Retrieved from http://visnykj.tneu.edu.ua/index.php/visnykj/article/view/684

7. Brych, V., Shpak, O., Dombrovsjkyj, Z., Tybinj, A., \& Dombrovsjkyj, M. (2013). Metody upravlinnja ryzykamy energhopostachaljnoji kompaniji [Risk manage-ment methods of the energy supply company] (304 p.). Ternopilj: TNEU. (In Ukrainian). Retrieved from https://cutt.ly/ea1MzRm

8. Chuchalin, M. (2017). Implementation of energy saving and enerhoefektive technologies in modern building. International scientific journal «Internauka», 1(23), 13-18. (In Ukrainian). Retrieved from https://www.inter-nauka.com/uploads/public/14851956495073.pdf

9. Dzhedzhula, V. (2014). Enerhozberezhennia promyslovykh pidpryiemstv: metodolohiia formuvannia, mekhanizm upravlinnia [Energy saving of industrial enterprises: methodology of formation, control mechanism] (346 p.). Vinnycja: VNTU. (In Ukrainian). Retrieved from http:// publish.vntu.edu.ua/txt/Dzed-zyla_594-6.pdf

10. Klymchuk, M. (2011). Systema upravlinnia biznes-protsesamy na pidpryiemstvakh alternatyvnoi enerhetyky [Business process management system at alternative energy enterprises]. Scientific Papers of the Bukovinian University. Economics, 7, 39-50. (In Ukrainian). Retrieved from http://zbirnuk.bukuniver. edu.ua/issue_articles/39.pdf

11. Mogilenko, A. (2016). Effekt otskoka (rebound effect) kak ukhudsheniye rezultata energosberegayushchikh meropriyatiy po sravneniyu s ozhidayemym [Rebound effect as a deterioration of the result of energy-saving measures in comparison with the expected one]. EnergoSovet, 5, 15-19. (In Russian). Retrieved from http://www.energosovet.ru/bul_stat.php?idd=622

12. Paljchuk, V. (2019). Enerhoefektyvni rishennia v hromadakh [Energy efficient solutions in communities]. Ukrajina: podiji, fakty, komentariUkraine: events, facts, comments, 18, 54-61. (In Ukrainian). Retrieved from http://nbuviap.gov.ua/images/ukraine/2019/18.pdf

13. Samojlenko, V. (2019). Enhancement of personnel qualification by the example of the leading countries of the world. Efektyvna ekonomika Efficient economy, 5. (In Ukrainian). https://doi.org/10.32702/2307-2105-2019.5.33

14. Santarius, T. (2015). Der Rebound-Effekt: ökonomische, psychische und soziale Herausforderungen für die Entkopplung von Wirtschaftswachstum und Energieverbrauch, Wirtschaftswissenschaftliche Nachhaltigkeitsforschung (341 p). Marburg: Metropolis-Verlag. Retrieved from https://www.metropolisverlag. de/Der-Rebound-Effekt/1176/book.do

15. Shvedun, V. (2018). Development and deployment of state policy of ukraine on energy saving and energy efficiency. Derzhavne upravlinnja: udoskonalennja ta rozvytok - Public administration: improvement and development, 12. (In Ukrainian). https://doi.org/10.32702/2307-2156-2018.12.1

16. Zaverbnyj, A. (2012). Analysis of reformation problems in the Ukrainian electric energy market. Visnyk Natsionalnoho universytetu «Lvivska politekhnika». Seriia: Menedzhment ta pidpryiemnytstvo v Ukraini: etapy stanovlennia i problemy rozvytku - Bulletin of the National University «Lviv Polytechnic»: Management and entrepreneurship in Ukraine: stages of formation and problems of development, 748, 311-321. (In Ukrainian). Retrieved from http:// ena.lp.edu.ua/handle/ntb/23249

17. Zlenko, A., \& Miroshnichenko, D. (2015). Professional development of personnel as pre-condition of increase of level of the labour productivity. Ekonomichnyi visnyk universytetu - Economic Bulletin of the University, 24(1), 34-38. (In Ukrainian). Retrieved from http://nbuv.gov.ua/UJRN/ ecvu_2015_24\%281\%29_8 